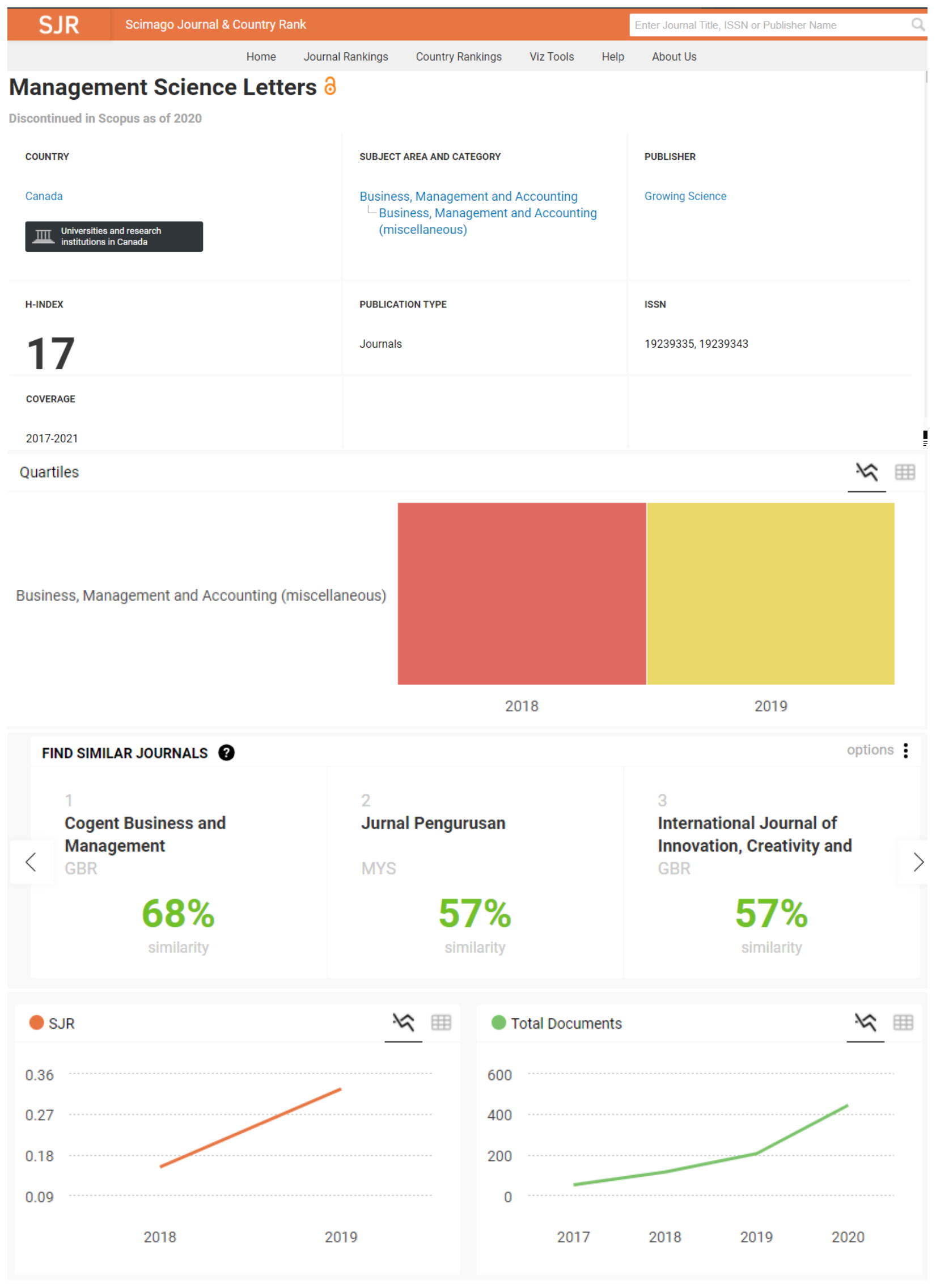




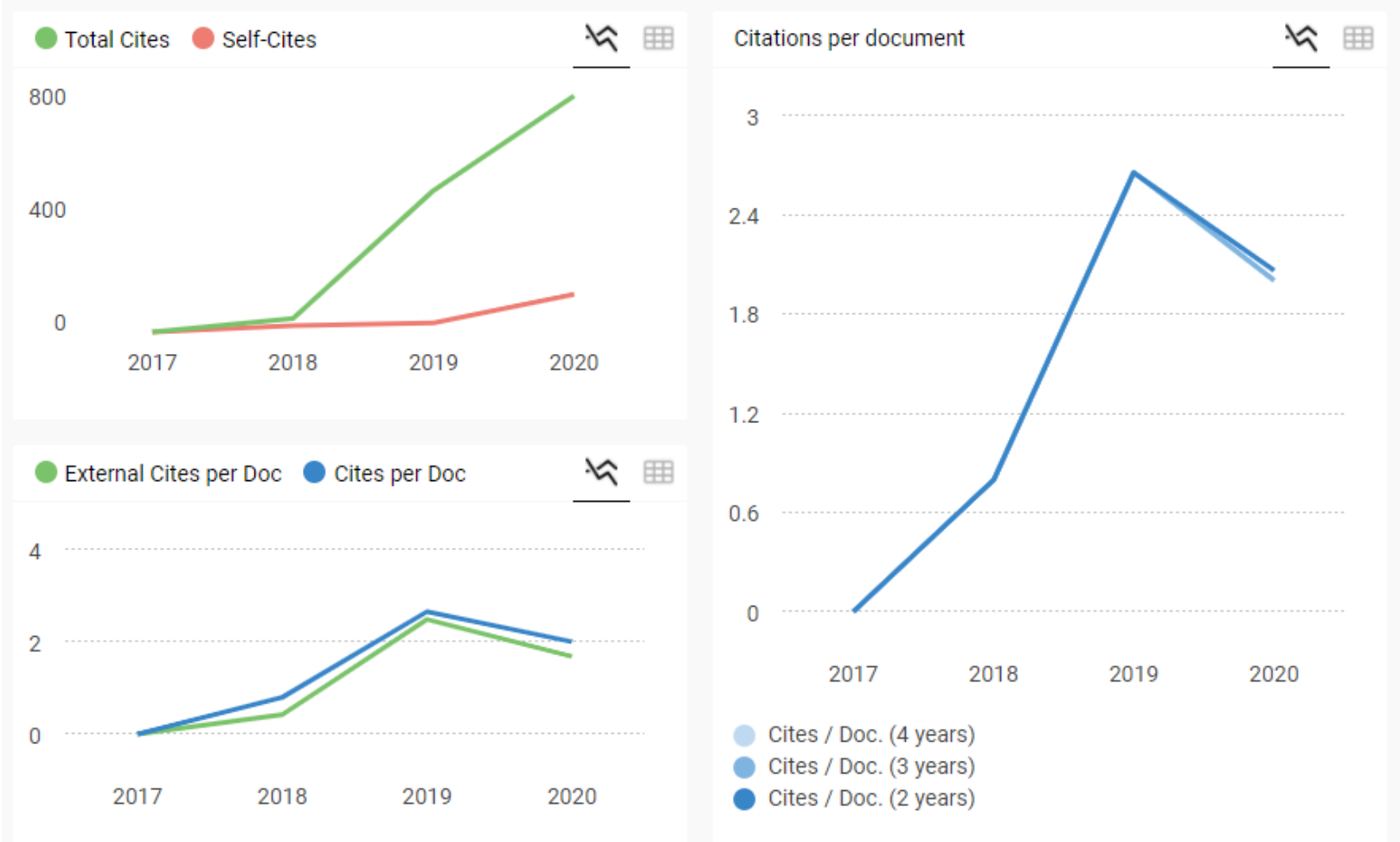




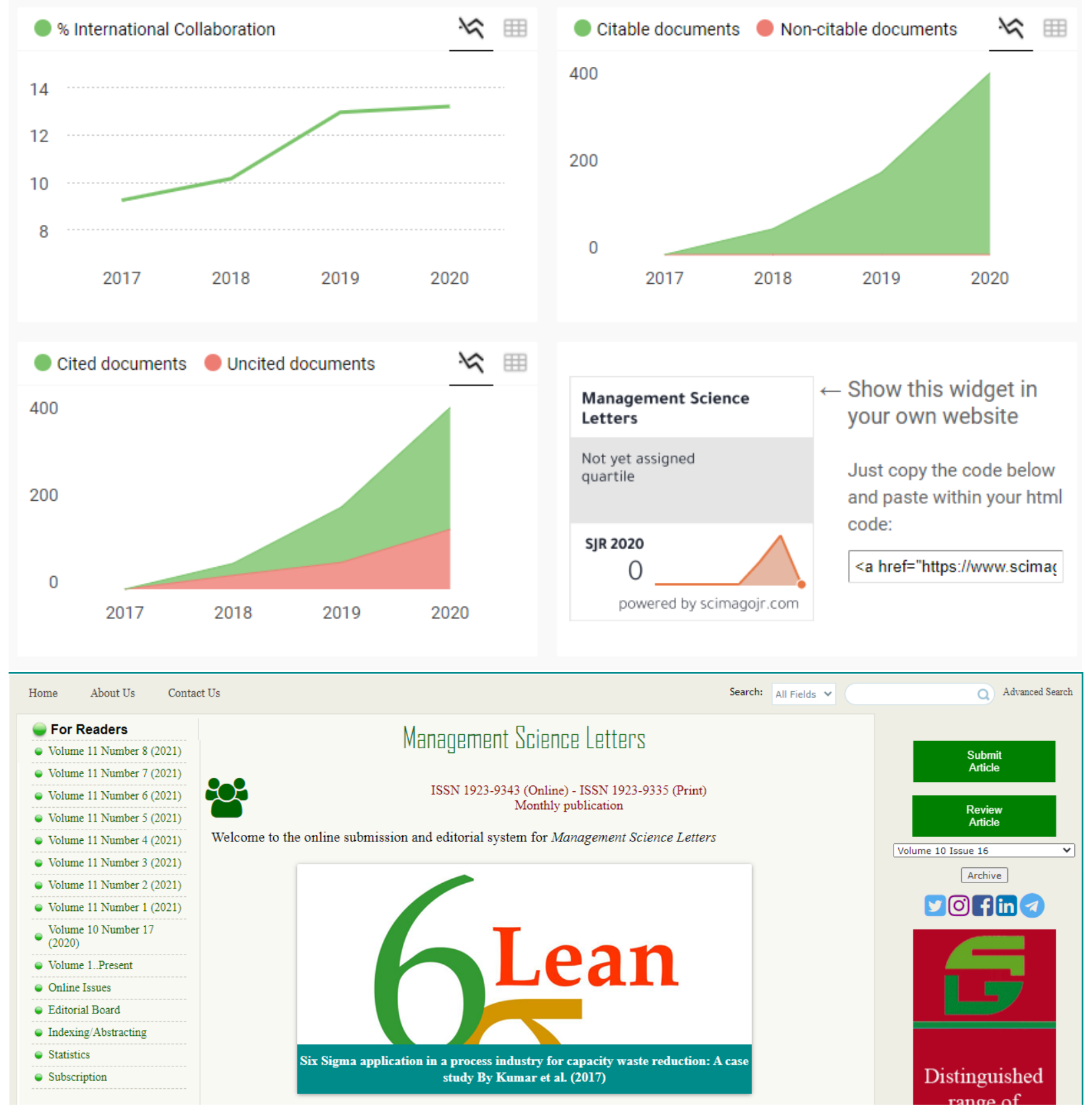




\begin{tabular}{l} 
For Authors \\
Author Guidelines \\
Submit Manuscript \\
Author Fee \\
Review Process \\
Ethics \\
\hline $\begin{array}{c}\text { Recommend } \\
\text { to } \\
\text { LIBRARY }\end{array}$
\end{tabular}

Management Science Letters is a peer reviewed, monthly publication dedicated to create a forum for scientists in all over the world who wish to share their experiences and knowledge in the field of management skills in the form of original, high quality and value added articles. The journal's policy is to perform a peer review on all submitted articles and the papers will be appeared in a form of online on our website as soon as the review result becomes positive. The journal covers both empirical and theoretical aspects of management and gives the chance on sharing knowledge among practitioners.

Management Science Letters is dedicated for publishing in the following areas:

- Quality Management

- Production Management (Scheduling, Production management, etc.)

- Total Quality Management (TQM)

- Six Sigma

- Production Efficiency

- Just in Time Inventory

- Data Envelopment Analysis

- Balanced Score Card

- Activity Based Cost (ABC)

- Technology Acceptance Model

- Brand Image, Commitment, Emotional Intelligence

- Marketing planning and Customer Relationship Management

- Critical Success Factors, Corporate Social Responsibility

- e-learning, Innovation, Creativity, Talent Management

- Customer satisfaction, Job satisfaction, Job turnover,

- Organizational commitment, Employee Commitment

- Knowledge Management, Leadership

- Knowledge sharing

- Human Resources Management (Employee training, Employee Performance, Work achievements,)

- Empowerment, Workplace Spirituality, Turnover Intention

- Small and medium-sized enterprises (SMEs) issues and Economic development

- Innovation, Creativity, Productivity and Performance

- Multi-Criteria Decision Making Applications in Management Science (AHP, BWM, TOPSIS, ...)

- Education Management, Social development, Public Policy

- Tourism Industry, Tourism promotion, Tourism directorates

- Business performance and financial performance

Management Science Letters is an open access journal, which provides instant access to the full text of research papers without any need for a subscription to the journal where the papers are published. Therefore, anyone has the opportunity to copy, use, redistribute, transmit/display the work publicly and to distribute derivative works, in any sort of digital form for any responsible purpose, subject to appropriate attribution of authorship. Authors who publish their articles may also maintain the copyright of their articles.

Management Science Letters applies the Creative Commons Attribution (CC BY) license to works we publish (read the human-readable summary or the full license legal code). Under this license, authors keep ownership of the copyright for their content, but permit anyone to download, reuse, reprint, modify, distribute and/or copy the content as long as the original authors and source are cited. No permission is needed from the authors or the publishers. Appropriate attribution can be provided by simply citing the original article (e.g., Hajiyan, H., Aminbeidokhti, A., \& Hemmatian, H. (2015). The effect of customer relationship management on customer loyalty: Evidence from banking industry. Management Science Letters, 5(11), 993-998. doi: 10.5267/j.ms1.2015.9.001). For any reuse or redistribution of a work, users have to also make clear the license terms under which the work was published. This broad license was developed to facilitate free access to, and unrestricted reuse of, original works of all kinds. Applying this standard license to your own work will ensure that it is freely and openly available in perpetuity.

Further Information

- Publishing credentials

$\checkmark$ News

Mission
Facts \& Figures

iv Facts

Open access

进 Joumal subscription
Follow Growing Science

f Facebook 이 Instagram

Twitter in Linkedin

(2) Telegram 


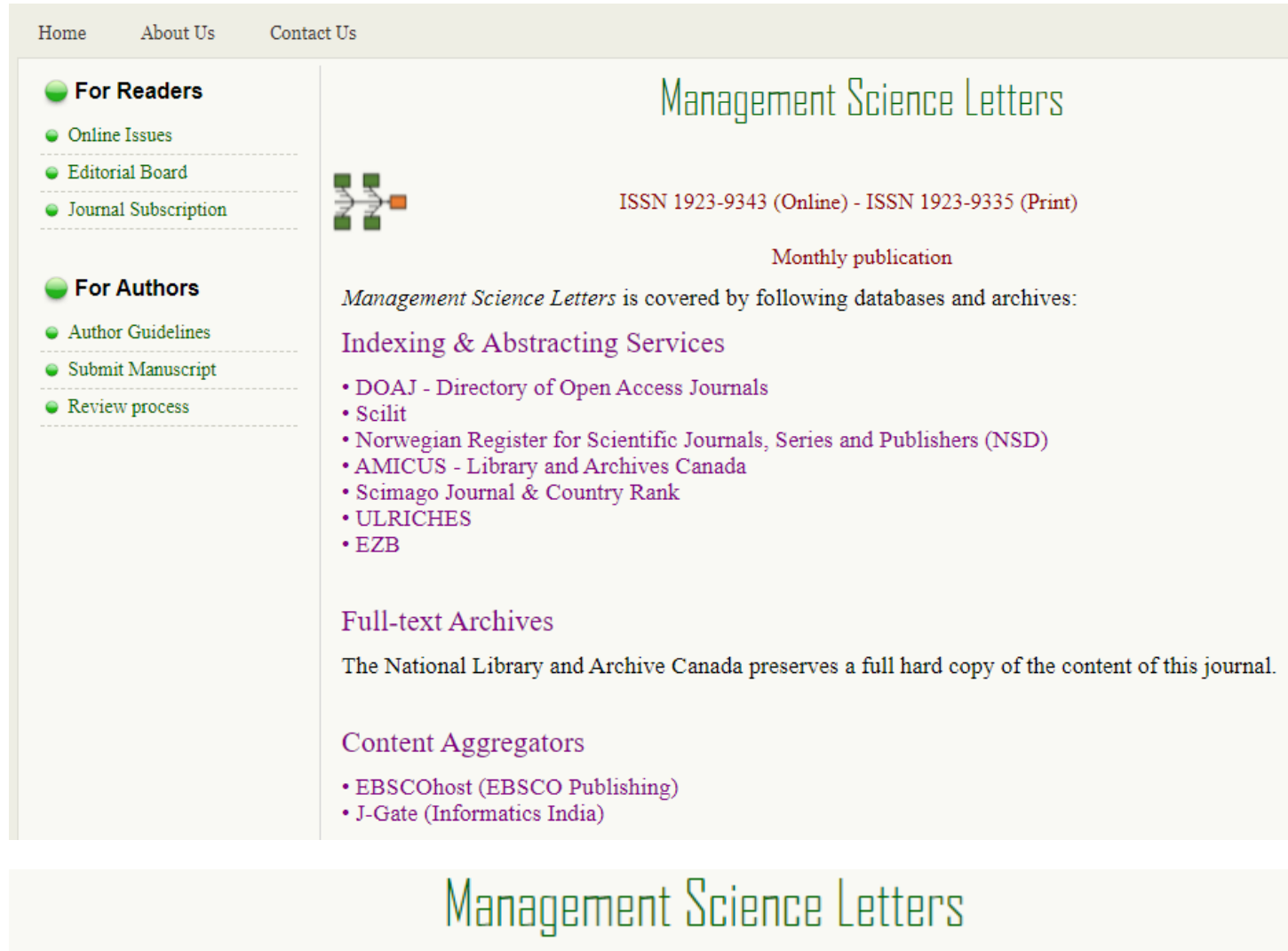

ISSN 1923-9343 (Online) - ISSN 1923-9335 (Print)

Monthly publication

Editor in chief

S. J. Sadjadi Department of Industrial Engieering, Iran University of Science and Technology, Iran

Editorial Board Members

Chien-Ho Ko National Pingtung University of Science and Technology, Taiwan

Zélia Silva Serrasqueiro Management and Economics Department, Beira Interior University, Portugal

Huyquan Vu, Deakin University, School of Information Technology, Geelong, Australia

Nilsen Kundakc1 Pamukkale University, Department of Business Administration, Denizli, Turkey

Jagdeep Singh Ludhiana College of Engineering and Technology, Ludhiana, India

Mostafa Jafari Iran University of Technology, Iran

Elyas Jazayeri University of Kentucky, USA

Payman Akhavan Malek Ashtar University of Technology, Iran

Nicola Miglietta Università degli Studi di Torino - Facoltà di Economia, Italy

Tam Bang Vu University of Hawaii at Hilo, United States

Leopoldo E. Cárdenas-Barrón Instituto Tecnológico y de Estudios Superiores de Monterrey, Mexico

Yee-Ming Chen Dept. of Industrial Engineering and Management, Taiwan

Sanjay Sharma National Institute of Industrial Engineering (NITIE), India

Bibhas C. Giri Jadavpur University, India

Dinh Tran Ngoc Huy Banking University - Ho Chi Minh City, Ho Chi Minh City, Viet Nam 
Adekunle Ibrahim Musa Moshood Abiola Polytechnic, Nigeria

Marcelo S. Nagano University of São Paulo, Brazil

Morteza Yazdani Universidad Europea de Madrid, Spain

Paulo S G De Mattos Neto Universidade Federal de Pernambuco, Brazil

Cao, Guangxi Nanjing University of Information Science and Technology, Collaborative Innovation Center on Forecast and Evaluation of Meteorological Disasters, Nanjing, China

Abderrahim Taamouti Durham University Business School, UK

Brian J. Galli Assistant Professor in the School of Computer Science, Innovation, and Management Engineering in the College of Management, Long Island University (LIU), USA

Prabha Bhola Indian Institute of Technology Kharagpur, 721302, West Bengal, India

Abbas Keramati Ryerson University, Canada

Amin Mahmoudi Southeast University, Nanjing, China

Advisory Members

Mojtaba Salehi K. T. Toosi University of Technology, Iran

\section{Volume 11 Issue 8 Pages 2175 - 2312 (2021)}

\section{Open Access Article}

The effect of supply chain integration on hotel performance through green supply chain management Pages: 2175-2184

Zeplin Jiwa Husada Tarigan, Fransisca Andreani and Sautma Ronni Basana 츠 PDF (288 K)

Abstract: Internal and external integration in hotel industries is essential to improve Green Supply Chain Management (GSCM) to maintain hotel performance and sustainability. This research is to examine the impact of internal and external integration on GSCM and hotel performance. It is quantitative research with judgmental sampling. Questionnaires were distributed to 72 hotel employees from 62 hotels of three-star hotels and above, who understand GSCM and hotel performance in East Java. But 66 questionnaires were returned, and only 62 questionnaires were valid for data analysis. Structural Equation Modelling (SEM) is used to analyze with the help of Java Web Start software. The results show that all six hypotheses are supported, internal integration with Use technology to significantly determine plans and coordination capable of external integration and GSCM. External integration with Sharing knowledge with partners and Collaborating in solving problems can improve GSCM significantly. Supply chain integration, which consists of internal integration and external integration, impacts hotel performance by reducing hotel waste and Efficient use of resources. GSCM in implementing Eco green, green procurement and product life cycle have a significant impact on improving hotel performance.

DOI: $10.5267 /$ j.msl.2021.5.002

Keywords: Internal integration, External integration, Green Supply Chain Management, Hotel performance

The effect of team value diversity on team performance: The mediating role of relationship conflict and the moderating effects of organization citizenship behavior and leader-member exchange quality Pages: 2185-2194

Abul Waleed, Wisal Ahmad, Muhammad Farooq Jan, Sadaqat Ali, Awais Jamal Khattak and Aamir Nadeem 츠 PDF (288 K)

Abstract: This paper aims to investigate the mediating role of relationship conflict and moderating role of organization citizenship behavior and leader-member-exchange quality on the relationship between team value diversity and team performance. Data was collected from 263 employees of the telecom sector addressing the variables of value diversity, team performance, relationship conflict, OCB and LMX. Regression analysis found that team value diversity negatively affects team performance, and relationship conflict significantly mediates this relationship. It was also found that $\mathrm{OCB}$ and LMX significantly moderate the relationship, such that in the presence of these two, value diversity doesn't affect team performance rather team performance is positive when these two are present. The findings of this research confirm that for effective management of team diversity in organizations, team leaders must also wisely manage relationship conflict.

DOI: $10.5267 /$ j.msl.2021.5.001

Keywords: Value diversity, Team performance, Relationship conflict, OCB, LMX 
A study on the success factors for knowledge management in supply chains of electronics industry Pages: 2195-2202 Vichayanan Rattanawiboonsom 츠 $P D F(288 \mathrm{~K})$

Abstract: This research aimed to 1) study the success factors for knowledge management through electronics industry supply chains, and 2) study guidelines and recommendations regarding the success factors for knowledge management through electronics industry supply chains. The study employed the quantitative research methodology. The statistical devices used included frequency, percentage and Structure Equation Modeling (SEM). The population and sample group comprised executives of the electronics industry in the electronics and electrical appliances sector in Thailand. The results revealed that the factors regarding the information technology system, leadership support and knowledge management had positive effects on the success of the knowledge management through electronics industry supply chains with the statistical significance $(\beta)$ of $0.519,0.621$ and 0.448 , respectively. However, the factors regarding human resource management affected the success of the knowledge management negatively at the statistical significance of 0.323 . As for the effects of variables on the success of the knowledge management, it was found that the factors with the most positive indirect effects (IE) and total effects (TE) were those regarding 1) leadership support $(\mathrm{IE}=0.278, \mathrm{TE}=0.278), 2)$ information technology system $(\mathrm{IE}=0.233, \mathrm{TE}=$ 0.233 ), and 3) knowledge management, which had a positive direct effect (DE) at 0.448 and a total effect (TE) at 0.448 . However, the factors regarding human resource management had a negative indirect effect (IE) on the success of the knowledge management at -0.145 .

DOI: $10.5267 /$ j.msl.2021.4.010

Keywords: Knowledge management, Knowledge process, Balanced scorecard

The effects of teaching and learning political economy in Vietnamese educational system Pages: 2203-2210

\section{Hien Van Tran 츠 PDF $(288 \mathrm{~K})$}

Abstract: This study aims to understand and test the factors influencing the effectiveness of learning and teaching political economy among Vietnamese universities. Over 1500 students from different majors and different school years have taken part in this study. The data collected from questionnaires was analyzed by SPSS version 2016 and EVIEW 10. From this study, it can be said that learning motivations and teaching methods are the most important factors driving the success of teaching and learning the political economy. Furthermore, males seem to be more interested in studying this subject and getting a higher GPA compared to females. Students from higher school-year, by contrast, have lower levels of interest in studying this module, leading to the lower effectiveness in teaching and learning this module. Finally, while teaching methods and teaching quality are positively correlated with the dependent variable, the administration service and infrastructure negatively influence the teaching and learning objectives.

DOI: $10.5267 /$ j.msl.2021.4.009

Keywords: Effectiveness, Teaching and learning, Political Economy, Vietnamese educational system

A comparison of adoption and service quality between large and small broadband internet service providers in Thailand Pages:

5. $\square \quad 2211-2224$

Kanokkarn Snae Namahoot and Viphasiri Jantasri 채 PDF $(288 \mathrm{~K})$

Abstract: This research aims to compare the influence of service quality on intention to use broadband internet through attitudes and technology acceptance, as mediator variables between large and small broadband internet service providers (ISPs) in Thailand. A comprehensive review of the literature has modified the development of this behavioral model that explains intention to use of broadband internet. A data set from two groups: large and small broadband ISPs, nationwide survey was conducted in Thailand ( $\mathrm{n}=928$ consumers). The theoretical model was tested using structural equation modeling. The findings show that integrated models have good explanatory power ( 78.3 percent) to predict customer's intention to use broadband internet. The results of this study are as follows. Firstly, service quality: tangible, reliability, responsiveness, assurance and empathy, supports second-order factor analysis. Service quality has an influence on attitude, perceived usefulness, perceived ease of use, and intention to use broadband internet both two types of service providers. Secondly, perceived usefulness has a significant effect on attitude, and intention to use only in small companies. Thirdly, attitude, perceived usefulness, and perceived ease of use as mediator variables have a positive effect between service quality and intention to use broadband internet. This study proposes customer acceptance on broadband internet using a modified TAM.to reveal the impact of service quality on intention to use. The results of this study can be replicated and extended to ASEAN countries. The conclusions and implications for management provide alternatives for companies to increase the number of internet users in order to improve overall quality of life.

DOI: $10.5267 /$ j.msl.2021.4.008

Keywords: Service quality, Attitude, Technology acceptance and intention to use broadband internet, SEM, Thailand

Does corporate social responsibility reduce financial distress? Evidence from emerging economy Pages: 2225-2232

Naeem Khan, Qaisar Ali Malik, Ahsen Saghir, Muhammad Haroon Rasheed and Muhammad Husnain tz PDF (288 K)

Abstract: This work investigates the relational behavior of corporate social responsibility (CSR) and its effect on firms' financial distress (FD). The population of the study consists of all the non-financial firms presently listed in the equity market of Pakistan. The yearly data set of 213 non-financial companies is selected from 2005 to 2017 with total observations of 2769 . The analysis of the study based on OLS regression, fixed effect, and random effect models. The study also uses the GMM technique to guard against potential problems of endogeneity and heteroskedasticity that arise from the use of panel data. Results indicate that higher investment in CSR leads to reduced/lower financial distress. It suggests that investment in CSR raises the reputation and creditworthiness of firms. Key findings are robust as confirmed by alternative proxies of financial distress. Overall findings advocate that CSR helps in reducing default risk or financial distress and creates a better corporate environment that ultimately improves organizations' economic outlook.

DOI: 10.5267/j.msl.2021.4.007

Keywords: CSR, FD, Z-Score, ZM-Score, Default Risk 
The effects of internet of things, strategic green purchasing and green operation on green employee behavior: Evidence from hotel 7. $\square$ industry Pages: 2233-2242

Sautma Ronni Basana, Zeplin Jiwa Husada Tarigan, Widjojo Suprapto and Fransisca Andreani 츠 PDF (288 K)

Abstract: Many people are aware of taking care of the global environment, so they demand environmentally friendly business activities. The government also has responded to the commotion by requiring companies to produce friendly and safe products or services to their customers. Hotel industries react to it by implementing the concept of green hotels. The purpose of this study is to examine whether the Internet of Things, strategic green purchasing and green operation have impacted green employee behavior in star-hotels in East Java. Eighty-two (82) questionnaires were distributed, but only 62 questionnaires were valid, with a response rate of $75.60 \%$. SEM-PLS (Structural Equation Modelling Partial Least Square) was used to analyze the data. The results show that the Internet of Things (IoT) has a significant impact on green hotel operation, with the $\mathrm{T}$-statistic value of 0.378 . green purchasing has a significant impact on green hotel operation, with the T-statistic value of 0.545 , and green employee behavior, with the T-statistic value of 0.346 . The Internet of things (IoT) has no significant impact on green employee behavior directly but through green hotel operation. The use of energy efficiency and the existence of good waste management as indicators of green hotel operation has an impact on green employee behavior of 0.346 .

DOI: $10.5267 /$ j.msl.2021.4.006

Keywords: Green employee behavior, Green operation, Green purchasing, Internet of things

An investigation of sales managers' aggressiveness in B2B sales leadership: The sequential mediation model of emotional

8. $\square$ exhaustion and adaptive selling Pages:2243-2254

Bilal Ahmad, Muhammad Imad ud Din Akbar, Mirza Huzaifa Asif and Naila Nureen 크 PDF (288 K)

Abstract: The aim of this research is to investigate the influence of sales managers' aggressiveness on ethical sales leadership and salesperson performance in $\mathrm{B} 2 \mathrm{~B}$ context, taking into consideration the sequential mediation of emotional labor and adaptive selling behavior. Sales managers spend most of their time in solving salesforce-related issues, while empirical studies have largely neglected such factors that can have negative consequences on salesforce-related tasks. In order to overcome this gap in the literature, we draw from conservation of resources (COR) theory to introduce and establish an advanced theoretical paradigm. The authors tested the model through 336 responses from B2B salesperson-manager dyads. The findings of the study reveal that sales managers' aggressiveness has a negative association with ethical sales leadership. Also, sales managers' aggressiveness is positively related to emotional exhaustion and negatively related to salesperson performance. Consequently, we found significant serial mediation of ethical sales leadership and adaptive selling behavior between the relationship of sales managers' aggressiveness and salesperson performance. In last, manager decisiveness is playing as a significant moderator in the study. Theoretical contributions and practical implications are also discussed.

DOI: $10.5267 / j . m s l .2021 .4 .005$

Keywords: Sales Managers' Aggressiveness, Ethical Sales Leadership, Emotional Exhaustion, Manager Decisiveness, Salesperson performance, B2B Selling

Drivers, barriers and incentives to implementing environmental management systems in the manufacturing industry Pages: 2255 -

9. $\square \quad 2260$

Nejah Ben Mabrouk and Saber Ibrahim 추 PDF $(288 \mathrm{~K})$

Abstract: Industrial development has made major breakthroughs in the last decade in the wake of increased production, government policies and public demand. At the same time, problems related to environmental sustainability have become a major concern for producers. The unsatisfactory dimension of environmental protection has always been highlighted, because the environmental management system (EMS) is ignored and not consistently implemented in certain Tunisian companies. This increasing interest in environmental consciousness is pushing manufacturers to aspire to adopt successful environmental management strategies. Organizations are in fact increasingly responsible for monitoring and enhancing their environmental efficiency. The present work is intended to resolve these issues by establishing the essential factors and modelling their interrelationships in the Tunisian context. By reviewing literature and expert opinions, 14 critical factors have been identified which leads to responsive in the implementation of EMS- based ISO 14001. For better understanding, the MICMAC research was used to identify the critical variables according to their driving and dependence power. The present study highlights "Top management commitment and support" and "Government policies and legislation" as the most significant factors for ISO 14001 implementation. This research will facilitate organizations' readiness for implementation of ISO 14001 by providing a detailed understanding of mutual relationships among EMS factors based on ISO 14001.

DOI: $10.5267 /$ j.msl.2021.4.003

Keywords: Environmental management system, ISO 14001, Driving factors, Interpretive structural modeling (ISM), MICMAC analysis

The impact of digital entrepreneurship on the environmental quality of agricultural companies: Evidence from agricultural

10. $\square$ companies in Jordan valley Pages: $2267-2278$

Elham Alhiary and Worood Alsaket ㅎ PDF $(288 \mathrm{~K})$

Abstract: The present study aimed to explore the impact of digital entrepreneurship on the environmental quality of agricultural companies. The population consists of $20 \mathrm{big}$ and middle sized companies. The sample consists of 85 individuals. A questionnaire was used for data collection. SPSS program was used. The dimensions of digital entrepreneurship are: (digital knowledge management, digital business environment management, and electronic leadership skills). The dimensions of environmental quality are: (top management commitment, ongoing improvement, and team work). Several results were reached. For instance, it was found that agricultural companies practice digital knowledge management for improving the environmental quality. However, such companies have been facing many challenges. Such challenges include: the fluctuations in the cash flow. The researcher recommends providing talented employees in agricultural companies with incentives. That shall enable those companies to keep up with the latest development in the field.

DOI: $10.5267 /$ j.msl.2021.4.002

Keywords: Digital entrepreneurship, Environmental quality, Agricultural companies 
The effect of intangible service quality on retailing during the COVID-19 pandemic in Saudi Arabia Pages:2279-2290 Zyad Alzaydi $\mathrm{t} P D F(288 \mathrm{~K})$

Abstract: The purpose of this study is to investigate how online to offline service quality influences the customer's perceived risk and trust towards the retailer and how these factors impact customer satisfaction and intention to revisit. The present study incorporates intangible service quality offline aspects, such as empathy, and online aspects, such as mobility. The objective of the research is to examine the integration of online to offline service quality models in Saudi Arabia during the COVID-19 pandemic, using key aspects of offline, online and mobile service quality. The data was collected using an online survey of 289 respondents from Saudi Arabia. The analysis was conducted using partial least square and structural equation modelling. This study finds that the intangibility of service quality has a positive impact on perceived trust; however, the direct relationship between the intangibility of service quality and perceived risk is not supported. The study's results support the hypothesis that customer satisfaction has a positive impact on the intention to revisit and that received trust positively affects satisfaction. The results have implications for service managers in the retailing and e-commerce sectors and offer a better understanding of how different channels of service affect customers' perceptions and intentions to revisit.

DOI: $10.5267 /$ j.msl.2021.4.001

Keywords: Online to Offline, Online Shopping, E-commerce, Retailing, Customer Satisfaction, Revisit Intention

Small-scale agricultural product marketing innovation through BUMDes and MSMEs empowerment in coastal areas Pages: 229112. $\square 2300$

Almasdi Syahza, Enni Savitri, Brilliant Asmit and Geovani Meiwanda 츠 PDF (288 K)

Abstract: A region's economic growth depends on the development policies based on the wealth determined from the potential of human, institutional and local resources. Furthermore, tThe development needs to link primary sectors with future processing to increase agricultural products' added value and marketing competitiveness. This study develops an innovative marketing model in agricultural products for small-scale farmers through village-owned enterprises (BUMDes) and micro, small, and medium enterprises (MSMEs) empowerment in coastal areas. One way of realizing this program is by building agribusiness and agro-industry partnerships that are wellplanned and associated with other economic sectors' development. The partnership involves community economic institutions, including BUMDes, credit institutions, farmer entrepreneurs, as well as Micro, Small, and Medium Enterprises. BUMDes is a rural-based business with a legal entity managed by the village government to create added value for the community's agricultural products. Together with MSMEs, these businesses need to support the agribusiness subsystem's development, including trading in agricultural production facilities and business activities. Furthermore, they need to promote agricultural production, support services, a source of market information for rural communities, the main actors of appropriate technology for agricultural products.

DOI: $10.5267 /$ j.msl.2021.3.015

Keywords: Rural economy, Marketing of agricultural products, BUMDes, MSMEs

Can innovation mediate the effect of adaptability, entrepreneurial orientation on business performance? Pages: 2301-2312

Enni Savitri, Emrinaldi Nur DP and Almasdi Syahza tㄹ PDF $(288 \mathrm{~K})$

Abstract: Business performance is one of the entrepreneurial behavior benchmarks. Small, and Medium Enterprises (SMEs) are required to have dynamic capabilities and strategies that can seize opportunities and improve the market. The aim of this paper is to analyze the effect of adaptability and entrepreneurial orientation on business performance through innovation as mediation. Based on interviews and questionnaires distributed to $115 \mathrm{SMEs}$ in coastal areas. The research results show that adaptability and entrepreneurial orientation have effects on innovation. Adaptability and entrepreneurial orientation have no effects on business performance. Innovation has effects on business performance. Adaptability and entrepreneurial orientation have effects on business performance through innovation as mediation. This study enriches the current literature by providing a contribution and insights to understanding how Resources Based View (RBV) theory affects business performance and innovation on SMEs in coastal areas in Indonesia. The implications of this study on entrepreneurship orientation in SMEs will help to increase resources for innovation. This emphasizes how the RBV approach used in this research helps improve business efficiency by leveraging existing capital in microbusinesses into a source of excellence. The government is working on policies to enhance the efficiency of SMEs in Indonesia.

DOI: $10.5267 /$ j.msl.2021.3.014

Keywords: Adaptability, Entrepreneurial Orientation, Innovation, Business Performance 


\title{
The effect of supply chain integration on hotel performance through green supply chain manage- ment
}

\author{
Zeplin Jiwa Husada Tarigan $^{a *}$, Fransisca Andreani ${ }^{\mathrm{b}}$ and Sautma Ronni Basana ${ }^{\mathrm{a}}$
}

\begin{tabular}{l}
${ }^{a}$ Management Department, Petra \\
${ }^{b}$ Master Management, Petra Chris \\
\hline C H R O N I C L E \\
\hline Article history: \\
Received: April 4, 2021 \\
Received in revised format: \\
April 242021 \\
Accepted: May 3, 2021 \\
Available online: \\
May 3, 2021 \\
\hline Keywords: \\
Internal integration \\
External integration \\
Green Supply Chain Management \\
Hotel performance
\end{tabular}

\section{Introduction}

Information technology has enabled customers to have more access and information to products or services they need faster and accurately, increasing demand for various products or services. Information technology also allows customers to go from one place to another place around the world quickly. The growth of global tourism is a significant problem in hotel availability for a tourist destination and becomes an essential issue in increasing the number of tourists in a country (Chou, 2014). One of the ways to do this is by making use of information technology. Hotel industries have implemented information technology to introduce hotel products or services by providing accurate and complete information. These industries build systems of information technology that are easy to use and integrate internally and externally with hotel partners for their competitive advantages. The information technology used by hotels is a combination of software, hardware, and humans to process some data to produce the information needed in decision making (Slim et al., 2021). Internal integration refers to the relationship among the organisation's functions to interact, coordinate and collaborate to solve problems faced by the company to produce outputs and outcomes (Danese et al., 2013; Siagian et al., 2020).

The information provided by the hotels for internal integration is related to data functions within the hotels to collaborate with the information needed by the external hotels. This internal information includes the number of hotel rooms, hotel facilities, and infrastructure. Hotel internal data are managed in such a way as to produce costs associated with the hotel, and later they are automatically integrated with external parties, namely hotel partners. Many companies have built business systems according to applicable regulations to make cost savings (Famiyeh et al., 2018). The collaboration built by the company with

\footnotetext{
* Corresponding author.

E-mail address: zeplin@petra.ac.id (Z. J. H. Tarigan)

\begin{abstract}
Internal and external integration in hotel industries is essential to improve Green Supply Chain Management (GSCM) to maintain hotel performance and sustainability. This research is to examine research with judgmental sampling. Questionnaires were distributed to 72 hotel employees from 62 hotels of three-star hotels and above, who understand GSCM and hotel performance in East Java.
But 66 questionnaires were returned, and only 62 questionnaires were valid for data analysis. Strucural Equation Modelling (SEM) is used to analyze with the help of Java Web Start software. The nificantly determine plans and coordination capable of external integration and GSCM. External ing shation with Showledge with partners and Collaborating in solving problems can imternal integration, impacts hotel performance by reducing hotel waste and Efficient use of resources. GSCM in implementing Eco green, green procurement and product life cycle have a sig-
\end{abstract}

(C) 2021 by the authors; licensee Growing Science, Canada 
suppliers/customers can increase environmental performance as workplace accidents have decreased in the last three years. Apart from that, the company's environmental location has also improved; and the company has reduced water waste.

Besides, external integration is done with suppliers and distributors/ retail and hotel customers by providing information to users to get accurate, complete and transparent communication when searching about the hotels. The internal and external integration is built by collaborating with partners to enable hotels to have efficiency and effectiveness of the process flow, product flow, information flow and cost flow. The relationships or integrated connections between suppliers, hotels and distributors/retail customers are called Supply Chain Management/ SCM (Lee et al., 2016). One key for companies to get SCM integration is by increasing companies' ability to design products or services more quickly by producing high-quality products or services at a lower cost when standing alone (Danese et al., 2013). SCM is also one of the main concerns for hotels to be done by becoming green hotels. Green hotel is an essential issue for global tourism-related to the green procurement process, the internal green process of the hotel, and green customers (Chou, 2014). They become a unity built by hotel management, and it is called Green Supply Chain Management (GSCM). Green Supply Chain Management requires a complete integrated system involving the hotels' core business, starting from purchasing environmentally friendly raw materials. Green Supply Chain Management was doing internal hotel processes that are environmentally friendly, providing hotel logistics systems that are environmentally friendly, and hotel activities related to eco green issues (Al-Ghwayeen \& Abdallah, 2018). GSCM is a practical business activity of an organization to maintain supplier stability, environmental stability and process stability for the organization. Green activities by hotels include implementing green supply chain management practices related to internal and external integration, eco-design, green procurement, and cooperation with customers. While for internal integration, it is related to internal environment management. GSCM combines green purchasing with green manufacturing/ process, green material management, green distribution/ marketing, and reversed logistics (Hervani et al., 2005). Green logistics supply chain management is the ability of businesses to carry out material transfers from upstream to downstream in paying attention to the environment by using technologies including logistics traceability, vehicle routing to reduce emissions, energy-saving management and collaborative logistics.

An organization practicing GSCM enables organizational performance improvement. Famiyeh et al. (2018) state that when an organization wishes to invest in GSCM practices, it will improve organizational performance through cost reduction, quality improvement, and organizational flexibility. Based on the explanation above, the purposes of this research are first to get the magnitude of the influence of internal integration on external integration, implementation of GSCM and hotel performance in East Java. Secondly, it is to find whether external integration has impacted the implementation of GSCM and hotel performance in East Java. Thirdly, it is to find out whether GSCM has influenced hotel performance in East Java.

\section{Literature Review}

\subsection{Technology Internal Integration}

Organizations or companies have managed their functions, either internally or externally (Siagian et al., 2020). Internally, organizations always cooperate, communicate, coordinate and even collaborate cross functions to achieve company goals. Khalaf and Mokadem (2019) state that by making use of information technology, companies can have good communication and coordination to increase productivity and efficiency in achieving organizational goals, and vice versa. If companies do not have good coordination and communication internally, it will be complicated to achieve companies' goals and objectives. Moreover, Wang and Dai's (2018) research shows that coordination and communication set up by a company would be able to create good internal integration and make customers satisfied (Hamali et al., 2020). Thus, customers will always remember the company's brand in their minds.

According to Huo et al. (2014), companies can build internal integration by matching their organizational functions to impact the companies in communicating and collaborating with external parties well to have external integration. The company can be done synchronizing the companies' systems with supplier systems and even with customer systems. Besides, Han et al. (2013) stated the company's internal integration could be done by collaborating operational planning among the organization's functions, implementing what has been planned, and coordinating the companies' objectives altogether intensively. The indicators used in technology internal integration are the technology used to determine plans together (x11), use technology to share data among departments (x12), use technology for data integration among departments (x13), and use technology to coordinate among departments (x14).

\subsection{External Integration}

Integration among departments within the organization will support its external integration with the customers or suppliers (Lee et al., 2016; Siagian et al., 2020). Al-Shboul et al. (2017) state that companies in the supply chain management flow related to the procurement of raw materials in partnership with suppliers, product/service processes with the roles of functions in the company, and external integration are built by companies in the supply chain management flow and integration with distributors/ retailers. Jajja et al. (2018) say that external integration can also be done by sharing sales forecast with their partners to enable to prepare materials; share products/ services' plans with suppliers and distributors/retailer/ customers; share 
product/service progress in the company with the distributors/retailers/ customers and share stock level inventory with the distributors/ retailers.

Most companies use the management of information systems (Hamali et al., 2020). It is measured by sharing product defects during the production process, production schedules, and machine breakdowns with the relevant departments. Process control is measured by processes done and process capabilities and equipment on the production floor altogether. Zhao et al. (2013) declare that integration with suppliers and distributors/retailers/customers will provide good information and support internal integration and vice versa. Companies need to involve partners to build product quality or service quality and provide effectiveness and efficiency in the company's operations (Elvers \& Song, 2016).

External integration can be to set goals together, share knowledge with external parties as a corporate partner, share risks and profits with partners, build promotions with partners, and share expertise in overcoming problems with partners (Woo et al., 2016). The indicators used in this study are risk-sharing with partners (x21), sharing values with partners (x22), sharing knowledge with partners (x23), and collaborating in solving problems (x24).

\subsection{Green Supply Chain Management (GSCM)}

Green Supply Chain Management (GSCM) is a process of moving material procurement, the process of materials into finished materials and the process of delivering products or services to customers by taking into account the environment to produce products or services more efficiently and effectively (Famiyeh et al., 2018; Hervani et al., 2005). According to Younis et al. (2016), GSCM refers to integrating organizational environmental conditions into the organization's process flow from supplier involvement to customer involvement through product or service design, raw material procurement, raw material selection, product manufacturing processes and final product delivery to customers as well as producing recycled products. Green practices in green supply chain management consist of green purchasing, green operations and green marketing (Çankaya \& Sezen, 2019). Hotels can practice green purchasing in the procurement of environmentally friendly materials, or materials that have a long lifetime, reusable materials, and materials that produce less waste, eco-label materials and others (Tarigan et al., 2020; $\mathrm{Xu}$ et al., 2019). Then, green operations include reducing the consumption of electrical energy, water consumption, disposable products, the use of plastic products, food waste, and having a good sanitation system and the like (Han et al., 2020). In addition to this, green marketing can be done by conducting marketing mix activities that are environmentally friendly (Çankaya \& Sezen, 2019). Al-Ghwayeen and Abdallah (2018) stated that the process of GSCM is related to the cooperation of companies with external parties, especially with suppliers in material procurement and selection. While with distributors, it has something to do with product sales, internal processes related to production processes, and company environments to maintain company sustainability. Furthermore, Sundram et al. (2018) also state that GSCM will enable the company to build internal and external integration by paying attention to the organizational environment. This study aims to measure the indicators of GSCM in hotels related to eco green (x31), green procurement (x32), product life cycle (x33), green products (x34), and green processes (x35).

\subsection{Hotel Performance}

Hotels are service industries that provide lodging facilities to the community, food and beverage products and laundry. Hotel chains increasingly emphasize commitments and policies related to the environment and business sustainability. Hotels implement green hotel practices in sustainable manners by considering consumer behavior towards environments and minimizing their impacts and maximizing long-term benefits. Organizations with more and more competitive advantages must measure their performances (Widjaja et al., 2020). Suitable hotel qualification and hotel performance improvement strategy are needed to maintain hotels' competitive advantages and sustainability. Hotels that have good performance will be the first choice of customers to use accommodation services. So, it can be said that the enormous number of hotel guests visiting and staying in the hotels, the hotels have implemented good competitiveness and maintained hotel performances well. Guest satisfaction is essential in the hotel industries. The level of guest satisfaction largely determines the level of hotel occupancy; thus, it also impacts the level of sales and profits (Scholz \& Voracek, 2016). Customers with environmental awareness are actively involved in environmental activities and always pay attention to the environment to become their habit. This type of hotel customers tends to pay attention to the application of green hotels, so they behave by carrying out activities related to saving electricity and water, reducing single-use hotel products, and using products repeatedly, especially hotel towels (Han et al., 2020). In hotel industries, employees can focus on activities related to environmentally friendly use of resources, including water resources, electricity resources, paper resources, hotel waste reduction, and equipment recycles. By doing so, hotels can provide products or services that are environmentally friendly to hotel guests (Luu, 2017). Market orientation and focus carried out by hotels on their customers will be able to have a direct impact on hotel performance (Hinson et al., 2017; Siagian et al., 2019). Alnawas and Hemsley-Brown's (2019) research towards 216 hotels in the UK shows that hotel performance consists of financial performance and economic performance. The ones that control financial performance and economic performance can be determined by hotel age, hotel size and hotel membership. Indicators used in this research on hotel performance are hotel operational performance related to green activities, which include ease of hotel booking through information technology (x41), commitment to the use of green products (x42), efficient use of resources (x43), and the reduction of hotel waste (x44). 
Internally, hotel industries can manage their operational functions well by cooperating, coordinating, and collaborating to achieve hotel goals. By using information technology, hotels can communicate, coordinate, and unite their operational functions to increase productivity and efficiency (Khalaf \& Mokadem, 2019). These can be done by executing what has been planned and coordinating the companies' objectives intensively (Wang and Dai, 2018). Well managed internal integration can be done by implementing Green Supply Chain Management (GSCM). It includes processes like moving material procurement, transforming materials into finished goods, delivering products or services to customers by paying attention to the environment to produce products or services in more efficient and effective manners (Famiyeh et al., 2018). Technology internal integration impacts supply chain management's flow, especially to suppliers, by sharing information effectively (Han et al., 2013). So, the first hypothesis is:

H1: Technology internal integration has influenced green supply chain management significantly.

Besides, hotels need to integrate their internal functions and their external functions as well. The hotel can match their operational processes to impact the hotels in communicating and collaborating with business partners to have external integration well (Huo et al., 2014). When hotels can integrate their internal functions well, it will support external hotel integration with suppliers or customers with the help of GSCM. GSCM enables hotels to integrate the conditions of hotel environments into the company's process flow involving both suppliers and customers through a product or service design, raw material procurement, raw material selection, product manufacturing processes and final product delivery to customers, as well as producing recycled products (Younis et al., 2016). External collaboration with suppliers can be in sharing problems faced by hotels, sharing innovative ideas with suppliers, sharing risks with suppliers and building excellent communication with suppliers, which can increase green firm performance for hotels (Tarigan et al., 2020). This collaboration with suppliers and collaboration with customers will positively impact environmental company performance (Lee \& Joo, 2020). Technology internal integration affects increasing external integration by sharing internal data with suppliers to make it easier for collaboration between partners (Han et al., 2013; Hamali et al., 2020). Integration with suppliers and distributors/ retailers or customers will accommodate good information and support internal integration and vice versa (Zhao et al., 2013; Siagian et al., 2020). Thus, hotels need to involve partners to build product or service quality well and provide companies' operations effectively and efficiently (Jajja et al., 2018). One of the ways is synchronizing the companies' systems with a supplier and even with customer systems. So, the following hypotheses in this research are:

H2: Technology internal integration has influenced external integration significantly.

$\mathbf{H}_{3}$ : External integration has influenced green supply chain management significantly

Coordination and communication set up by hotels can provide good internal integration and satisfy customers since this plays an essential role in making customers remember the company's brands (Wang and Dai, 2018). Having well internal integration can enable hotels to produce good quality products and services. Thus, it may boost hotel performance. Internally, companies can use their abilities to create a cross-functional team together to resolve problems among departments and collaborate among functions well to improve company performance by increasing sales, increasing market share, increasing profit, and customer satisfaction (Han et al., 2013). Internal integration can improve company performance significantly in manufacturing industries (Slim et al., 2021; Tarigan et al., 2018; Widjaja et al., 2020; Hamali et al., 2020). Furthermore, maintaining hotel qualification and hotel performance plays a crucial role in this high competition. Hotels need to keep their competitive advantages to perform well and survive. Customers tend to choose and stay in hotels with good performance than those that do not have good performance. Suitable hotel qualification and hotel performance will become the first choice for customers to keep as it can satisfy the offered products or services. The hotel occupancy level is mainly determined by the guest satisfaction level (Scholz \& Voracek, 2016). So, the further hypothesis is:

H4: Technology internal integration has influenced hotel performance significantly.

Moreover, companies' external integration in the supply chain management flow has something to do with the procurement of raw materials in partnership with suppliers, product/ service processes within the functions in the company, and integration with distributors/ retailers Al-Shboul et al. (2017). It can also be done by sharing sales forecasts with the company's partners, products or services' plans, sharing product or service progress of the companies, and sharing risks with their business partners (Jajja et al., 2018; Woo et al., 2016). By doing so, the companies can implement GSCM well. GSCM process is associated with companies' cooperation with their external parties or business partners, especially with suppliers in material procurement and selection and distributors in product sales. Besides that, it is also related to internal processes, especially in the company environment, to maintain company sustainability (Al-Ghwayeen \& Abdallah, 2018). Implementing GSCM can enable companies to build internal and external integration environmentally-friendly (Sundram et al., 2018). Hotel employees can pay attention to environmentally friendly activities by using water/ electricity/ paper resources efficiently and reducing hotel waste and recycling equipment when needed to produce environmentally friendly products or services to customers (Çankaya and Sezen, 2019). By focusing on market orientation, hotels will boost hotel performance (Tarigan et al., 2020; Xu et al., 2019). Therefore, the following hypotheses are: 
H5: External integration has influenced hotel performance significantly.

H6: Green supply chain management has influenced hotel performance significantly.

The research model is per Figure 1 below.

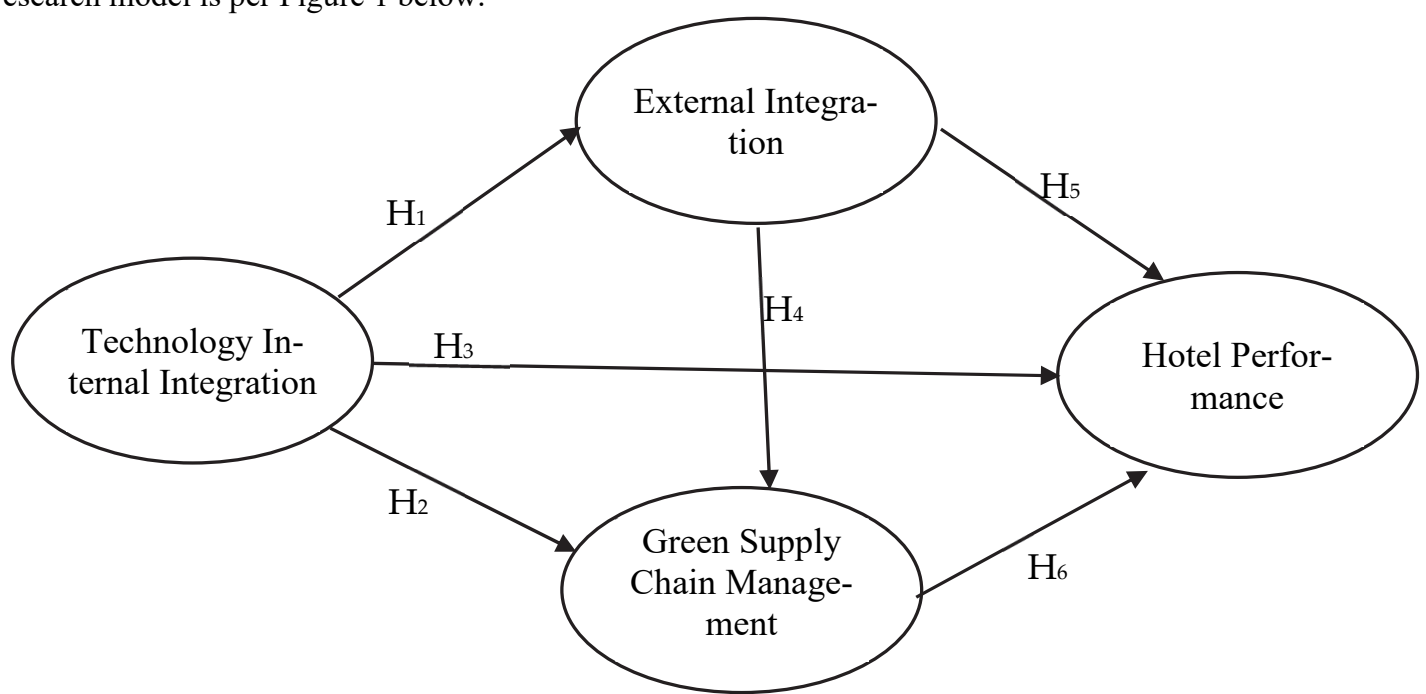

Fig. 1. Research Model Green Supply Chain Management in Hotel Performance

\section{Methods}

The population can be explained as a comprehensive group of individuals, institutions, objects, and so forth with common characteristics that become a researcher's interest (Sekaran \& Bougie, 2016). This research involves hotel employees of threestars-hotels (classified by traveloka.com, agoda.com and Surabaya Tourism Office) in East Java. Judgmental sampling is used with the following criteria. The respondents are three-star hotel employees who understand the implementation of green hotels and have been working in related departments for at least two years or the ones who have become permanent hotel staff for two years. Questionnaires were distributed to 72 hotel employees from 62 three-star-hotels. Sixty-six (66) questionnaires were returned, but only 62 questionnaires were valid for data analysis. So, the response rate is $86.11 \%$. The statistical descriptive analysis seen in Table 1 . Table 1 shows that the respondents in this research are primarily males, which indicates that most jobs in hotel industries are done by males. In terms of education, most respondents are undergraduates (S1 degree), and some others are postgraduates (S2 degree). So, it can be said that hotels also take into account the managerial skills of their employees and technical skills to serve customers well. These qualifications can enable employees to make use of information technology and implement green hotels better. Moreover, the respondents who have been working for more than three years (32\%) also indicate that employees have understood hotel management policies and departmental programs quite well to achieve hotel strategic targets. Besides, most of the respondents are from the food and beverage department, as many as 23 respondents $(36 \%)$. This department has established policies related to green hotels, especially food and beverage waste. The food and beverage department is a part of the hotel, which manages and ensures standard operating procedures to be done well in all related areas of the hotel regarding food and beverages distribution.

Table 1

The Characteristics of Respondents

\begin{tabular}{|c|c|c|c|}
\hline Characteristics & Description & Frequency & Percentage \\
\hline \multirow{2}{*}{ Gender } & Male & 35 & $56 \%$ \\
\hline & Female & 27 & $44 \%$ \\
\hline \multirow{2}{*}{ Education } & S1 degree & 56 & $90 \%$ \\
\hline & S2 degree & 6 & $10 \%$ \\
\hline \multirow{4}{*}{ Length of Work } & $2-3$ years & 30 & $48 \%$ \\
\hline & $4-5$ years & 20 & $32 \%$ \\
\hline & 6- 7 years & 7 & $12 \%$ \\
\hline & More than seven years & 5 & $8 \%$ \\
\hline \multirow{4}{*}{ Department } & Housekeeping & 19 & $31 \%$ \\
\hline & Front office & 13 & $21 \%$ \\
\hline & Food and Beverage & 23 & $36 \%$ \\
\hline & Pastry & 7 & $12 \%$ \\
\hline \multirow{3}{*}{ Duration of green hotel implementation } & $1-3$ years & 43 & $69 \%$ \\
\hline & $4-5$ years & 17 & $27 \%$ \\
\hline & More than five years & 2 & $4 \%$ \\
\hline
\end{tabular}

The respondents from the housekeeping department are 19 respondents (31\%), who are in charge of cleaning and maintaining the hotel area. It includes guests' rooms, parking area, public area (lobby, restaurants, swimming pools, gardens, tennis courts, 
and the like), linen and laundry rooms, as well as rented rooms such as arcades, drugstores, banks, money changers, travel agents, beauty salons, barbershops, meeting rooms, and others. There are four variables in this research. First, internal integration has something to do with data integration within the hotels. Second, external integration is related to information technology that can be accessed well by suppliers, distributors and customers. Third, Green Supply Chain Management (GSCM) is concerned with activities carried out by environmentally friendly hotels. Fourth, hotel performance refers to hotel operational performance related to green activities. The data analysis technique used is a quantitative research using SEM (Semi Equation Modeling) with smart PLS software version 2.0 (Hair et al., 2019). Moreover, data are analyzed using Java web start program, which is a form of Structural Equation Modeling (SEM) with validity and reliability tests as per Table 2. Table 2 shows that the average mean of internal technology integration is 4.0121, indicating that hotels have implemented and integrated their information technology systems in all departments quite well. The average mean between 3.8548 to 4.1935 is considered good. Thus, it also impacts their external integration with hotel business partners. The average mean of external integration is 4.0202 showing that hotels have coordinated and integrated their system with suppliers/distributors' systems. The least mean value is collaborating in solving problems (x24) as much as 3.7903, and the highest mean value is risk-sharing with partners $(\mathrm{x} 21)$ as much as 4.2258 . Hotels have been able to integrate externally by sharing information and risk with business partners to achieve mutual coordination and understanding to fulfill both parties' needs. Furthermore, green supply chain management activities have an average mean of 4.1032, representing that hotel GSCM has done well. The least mean value is product life cycle (x33), as much as 3.9355, and the highest mean value is green procurement (x32) as much as 4.1452. Green supply chain management shows that hotels have considered material procurement accordingly by paying attention to environmental factors. Then, the average mean value of hotel performance is 4.1935 , indicating that hotels can perform well. Tcanalue is the ease of hotel booking through technology (x41) and commitment to the use of green products ( $\mathrm{x} 42)$ as much as 4.1985, and fulfil mean value is the efficient use of resources ( $\mathrm{x} 43$ ) as much as 4.0806.

Table 2

Model Measurement

\begin{tabular}{lllll}
\hline Measurement Model & Mean & STDEV & Loading & Remark \\
\hline Technology of Internal Integration (Reliability) & 4.0121 & 0.6581 & 0.817 & Reliable \\
Use technology to determining plans together (x11) & 4.1935 & 0.6230 & 0.721 & Valid \\
\hline Use technology to sharing data (x12) & 4.0484 & 0.7112 & 0.619 & Valid \\
Use technology for data integration (x13) & 3.8548 & 0.6232 & 0.687 & Valid \\
Use technology to coordinate (x14) & 3.9516 & 0.6383 & 0.869 & Valid \\
\hline External Integration (Reliability) & 4.0202 & 0.8367 & 0.877 & Reliable \\
Risk-sharing with partners (x21) & 4.2258 & 0.7557 & 0.771 & Valid \\
Sharing values with partners (x22) & 4.0968 & 0.9181 & 0.806 & Valid \\
Sharing knowledge with partners (x23) & 3.9677 & 0.8487 & 0.810 & Valid \\
Collaborating in solving problems (x24) & 3.7903 & 0.7711 & 0.814 & Valid \\
\hline GSCM (Reliability) & 4.1032 & 0.6983 & 0.847 & Reliable \\
Eco green (x31) & 4.0484 & 0.6635 & 0.810 & Valid \\
Green procurement (x32) & 4.1774 & 0.6901 & 0.752 & Valid \\
Product life cycle (x33) & 3.9355 & 0.8272 & 0.744 & Valid \\
Green products (x34) & 4.1452 & 0.6490 & 0.745 & Valid \\
Green processes (x35) & 4.2097 & 0.6308 & 0.562 & Valid \\
\hline Hotel Performance (Reliability) & 4.1935 & 0.6933 & 0.787 & Reliable \\
Ease of hotel booking through technology (x41) & 4.2581 & 0.6256 & 0.525 & Valid \\
Commitment to the use of green products (x42) & 4.2581 & 0.6998 & 0.645 & Valid \\
Efficient use of resources (x43) & 4.0806 & 0.7082 & 0.687 & Valid \\
Reduction of hotel waste (x44) & 4.1774 & 0.7361 & 0.890 & Valid \\
\hline
\end{tabular}

Initial data processing is done by testing the validity of the research indicators. The validity test's results of internal integration indicators are as follows: determining plans together (original sample estimate 0.721 , t-statistic 4.868), sharing data among departments (original sample estimate 0.619, t-statistic 3.084), data integration among departments (original sample estimate 0.687, t-statistic 4.085), and coordinating among departments (original sample estimate 0.869, t-statistic 4.316). The results of external integration indicators are: risk-sharing with partners (original sample estimate 0.771, t-statistic 10.107), sharing values with partners (original sample estimate 0.806 , t-statistic 10.333), sharing knowledge with partners (original sample estimate 0.810 , t-statistic 11.039), collaborating in solving problems (original sample estimate 0.814 , t-statistic 11.709).

Then, the results of GSCM indicators are as follows: eco green (original sample estimate 0.810, t-statistic 9.611), green procurement (original sample estimate 0.752 , t-statistic 6.591 ), product life cycle (original sample estimate 0.744 , t-statistic 5.713 ), green products (original sample estimate 0.745 , t-statistic 4.860), and green processes (original sample estimate 0.562 , t-statistic 2.322). While the validity test of hotel performance indicator is easy hotel bookings through information technology (original sample estimate 0.525 , t-statistic 2.764), commitment to the use of green products (original sample estimate 0.645 , t-statistic 4.623), efficient use of resources (original sample estimate 0.687 , t-statistic 6.108), and hotel waste reduction (original sample estimate 0.890 , $t$-statistic 27.666). All indicators in this research are valid as their original sample estimate is 
above 0.50 with a t-statistic and higher than 1.96. Furthermore, the composite reliability test of four variables is as follows: internal integration (0.817) and external integration (0.877). GSCM (0.847), and hotel performance (0.787). So, the variable can be said that all four variables are reliable as composite reliability values are higher than 0.70 .

\section{Data Analysis and Discussion}

The results of the six hypotheses in this research are shown in Fig. 2 and Table 3. The Results indicate the magnitude of the influence between one variable and another.

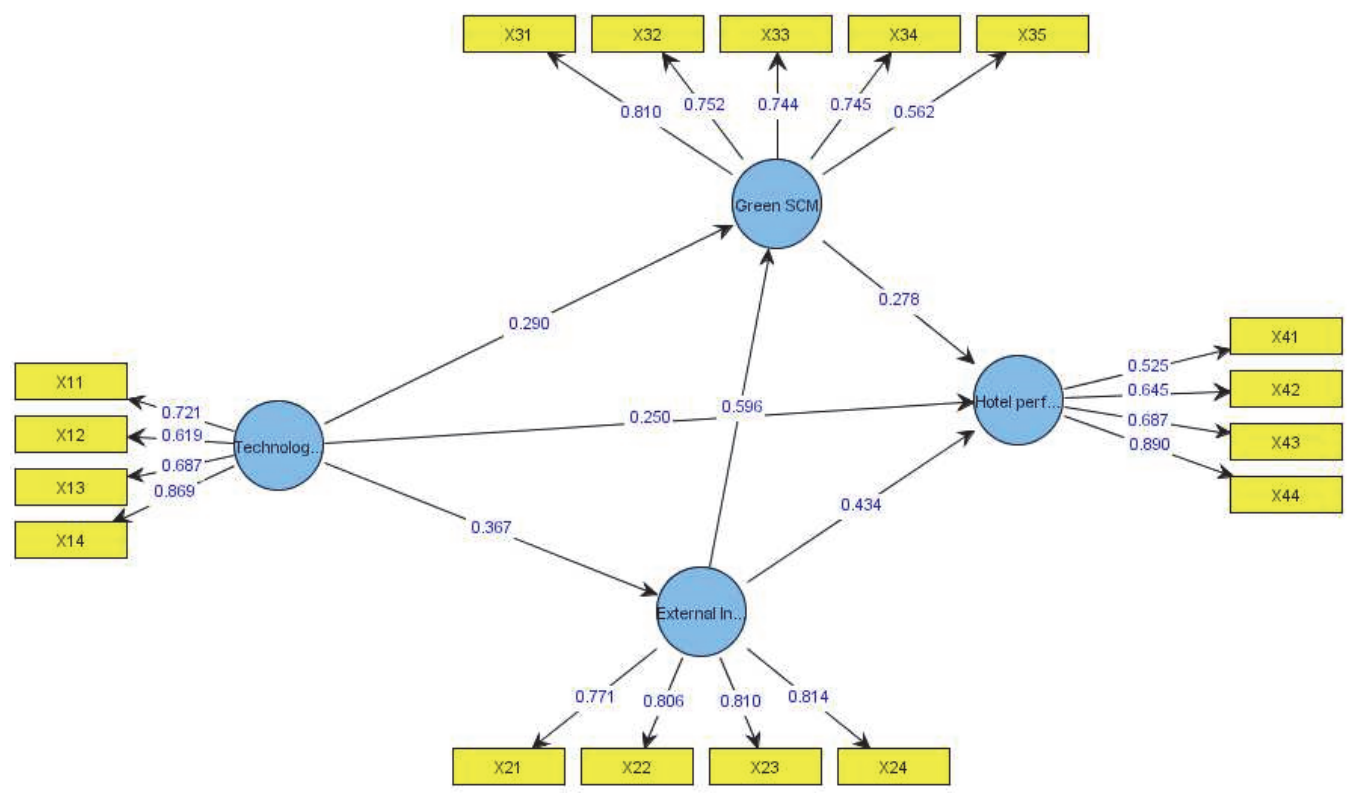

Table 3

Fig. 2. The results of testing the hypotheses

Results for Inner Weight

\begin{tabular}{lllll}
\hline Hypothesis & Original sample & Mean & STDEV & t-statistic \\
\hline Technology Internal Integration $\rightarrow$ GSCM & 0.290 & 0.362 & 0.109 & 2.305 \\
Technology Internal Integration $\rightarrow$ External Integration & 0.367 & 0.355 & 0.115 & 2.185 \\
Technology Internal Integration $\rightarrow$ Hotel Performance & 0.250 & 0.279 & 0.109 & 1.980 \\
External Integration $\rightarrow$ GSCM & 0.596 & 0.572 & 0.107 & 5.579 \\
External Integration $\rightarrow$ Hotel Performance & 0.434 & 0.406 & 0.124 & 3.504 \\
GSCM $\rightarrow$ Hotel Performance & 0.278 & 0.411 & 0.125 & 2.051 \\
\hline
\end{tabular}

Based on Fig. 2 and Table 3, internal integration has influenced GSCM as much as 0.290 significantly with t-statistic $2.305>$ 1.960. So, the first hypothesis (H1) is supported. It shows that hotels can synchronize operational planning among departments within the hotels quite well by sharing data. Using a data integration system, hotels can coordinate functional departments effectively and efficiently. In this way, hotels can implement GSCM well to produce products or services that are environmentally friendly. Besides, hotels that have implemented internal integration can affect their external integration, which is as much as 0.367 and significantly with t-statistic 2.185 (> 1.960). Thus, the second hypothesis (H2) is supported. Hotels can cooperate and collaborate with their distributors/ suppliers/ customers by sharing risk. Besides that, hotels can also share values and knowledge with their business partners by making product or service innovation. When problems arise, hotels can solve problems together with their distributors/ suppliers/ customers by providing customer service to handle their complaints and feedback. Furthermore, internal integration has influenced hotel performance as much as 0.250 significantly (t-statistic $1.980>1.960)$. So, the third hypothesis (H3) is supported. When hotels can coordinate all departmental functions well, they will have efficient procurements, reduce the production cost, and cut product waste. Thus, they can produce good product/ service quality well. The higher the hotel performance they have, the more satisfied the customers towards their products or services offered by the hotels. This research supports Tarigan et al. (2018), which states that the internal integration system impacts increasing company performance.

In this research, external integration has influenced GSCM as much as 0.596 significantly with a t-statistic $5.579>1.960$. This hypothesis can be said that the fourth hypothesis (H4) is supported. By sharing risk, values and knowledge with business partners, hotels can solve problems using synchronized and integrated information systems. The systems, called GSCM, enable hotels to have eco-green procurement by paying attention to product life cycles. Hotels can also be able to process green 
products or services that are environmentally friendly. Moreover, external integration has influenced hotel performance as much as 0.434 significantly as the t-statistic is $3.504>1.960$. Thus, the fifth hypothesis (H5) is supported. Sharing risk, values and knowledge with distributors/ suppliers/ customers will enable hotels to solve problems together. Using information technology, hotels can synchronize the systems well by providing easy hotel bookings and green products/ services for their customers, using efficient resources that can reduce hotel waste. This study is in line with Tarigan et al. (2020), stating that a well-built external collaboration can significantly impact green firm hotel performance.

Finally, GSCM has also influenced hotel performance significantly, as much as 0.278 , with a t-statistic $2.501>1.960$. Therefore, the sixth hypothesis (H6) is supported. Implementing GSCM enables hotels to have co green procurement from their business partners. Hotels can also take into account their product life cycles in processing green products/ services. Hotels that focus on implementing green operations and material procurement are unique and become the choice for customers who care and are aware of the environment (Han et al., 2020). GSCM helps hotels to cut cost and waste so that it will boost hotel performance.

\section{Conclusions}

All six hypotheses in this research are supported. The implementation of information technology can provide benefits for hotels by integrating GSCM internally and externally. Internally, hotels can manage efficient and effective business activities to achieve hotels' objectives and goals by integrating all departmental functions faster. This well-managed integration will directly affect hotels' external integration with business partners. When hotels can synchronize both internal and external integration using GSCM to maintain and produce environmentally and friendly products or services, it will escalate hotel performance simultaneously. By doing so, hotels can be sustainable in rapid and dynamic changes.

This research has shown the importance of internal and external integration for business processes using GSCM that can affect hotel performance. Thus, coordinating and collaborating with business partners is crucial for hoteliers to survive as competition is getting more arduous and challenging. Hotel managers must be able to get their competitive advantages to sustain in this dynamic era. For further research, it is recommended to have more comprehensive respondents with a grander scale as this research is focused on hotels in East Java only. It would be advisable to use this research as a benchmark or employ other related variables to boost hotel performance.

\section{References}

Al-Ghwayeen, W.S., \& Abdallah, A.B. (2018). Green supply chain management and export performance: The mediating role of environmental performance. Journal of Manufacturing Technology Management, 29(7), 1233-1252, https://doi.org/10.1108/JMTM-03-2018-0079.

Alnawas, I., \& Hemsley-Brown, J. (2019). Market orientation and hotel performance: investigating the role of high-order marketing capabilities. International Journal of Contemporary Hospitality Management, 31(4), 1885-1905, https://doi.org/10.1108/IJCHM-07-2018-0564.

Al-Shboul, M.A.R., Barber, K.D., Garza-Reyes, J.A., Kumar, V., and Abdi, M.R. (2017). The effect of supply chain management practices on supply chain and manufacturing firms' performance. Journal of Manufacturing Technology Management, 28(5), 577-609, https://doi.org/10.1108/JMTM-11-2016-0154

Çankaya, S.Y., \& Sezen, B. (2019). Effects of green supply chain management practices on sustainability performance. Journal of Manufacturing Technology Management, 30(1), 98-121, DOI 10.1108/JMTM-03-2018-0099

Chou, C.J. (2014). Hotels' environmental policies and employee personal environmental beliefs: interactions and outcomes. Tourism Management, 40, 436-446, https://doi.org/10.1016/j.tourman.2013.08.001

Danese, P., Romano, P., \& Formentini, M. (2013). The impact of supply chain integration on responsiveness: the moderating effect of using an international supplier network. Transportation Research Part E: Logistics and Transportation Review, 49(1), 125-140, https://doi.org/10.1016/j.tre.2012.08.002

Elvers, D., \& Song, C.H. (2016). Conceptualizing a framework for customer integration during new product development of chemical companies. Journal of Business \& Industrial Marketing, 31(4), 488-497. https://doi.org/10.1108/ JBIM-12-20140262

Famiyeh, S., Kwarteng, A., Asante-Darko, D., \& Dadzie, S.A. (2018). Green supply chain management initiatives and operational competitive performance. Benchmarking: An International Journal, 25(2), 607-631, https://doi.org/10.1108/BIJ10-2016-0165

Hair, J.F., Risher, J.J., Sarstedt, M., \& Ringle, C.M. (2019). When to use and how to report the results of PLS-SEM. European Business Review, 31(1), 2-24. https://doi.org/10.1108/EBR-11-2018-0203

Hamali, S., Prihandoko, D., Kurniawan, S., \& Ramadhani, R. (2020). The effects of supply chain information integration on organizational performance in food small industry. Management Science Letters, 10(3), 695-702, DOI: 10.5267/j.msl.2019.9.009

Han, H., Chen, C., Lho, L.H., Kim, H., \& Yu, J. (2020). Green hotels: exploring the drivers of customer approach behaviors for green consumption. Sustainability, 12(21), 9144, 1-14, doi:10.3390/su12219144 
Han, J., Lu, H., Trienekens, J.H., \& Omta, S.W.F. (2013). The impact of supply chain integration on firm performance in the pork processing industry in China. Chinese Management Studies, 7(2), 230-252, DOI 10.1108/CMS-Jun-2011-0034

Hervani, A.A., Helms, M.M., \& Sarkis, J. (2005). Performance measurement for green supply chain management. Benchmarking: An International Journal, 12(4), 330-353, HTTP:// doi.org/10.1108/14635770510609015

Hinson, R., Abdul-Hamid, I., \& Osabutey, E. (2017). Investigating market orientation and positioning in star-rated hotels in Ghana. International Journal of Contemporary Hospitality Management, 29(10), 2629-2646, https://doi.org/10.1108/IJCHM-02-2016-0075.

Huo, B., Qi, Y., Wang, Z., \& Zhao, X. (2014). The impact of supply chain integration on firm performance, the moderating role of competitive strategy. Supply Chain Management: An International Journal, 19(4), 369-384, DOI 10.1108/SCM03-2013-0096.

Jajja, M.S.S., Chatha, K.A., \& Farooq, S. (2018). Impact of supply chain risk on agility performance: Mediating the role of supply chain integration. International Journal of Production Economics, 205, 118-138, https://doi.org/10.1016/j.ijpe.2018.08.032

Khalaf, M.A., \& Mokadem, M.Y.E. (2019). The relationship between internal integration and manufacturing flexibility in the Egyptian industry. International Journal of Quality and Service Sciences, 11(1), 16-33, https://doi.org/10.1108/IJQSS-062017-0052

Lee, H.-Y., Seo, Y.-J., \& Dinwoodie, J. (2016). Supply chain integration and logistics performance: the role of supply chain dynamism. The International Journal of Logistics Management, 27(3), 668-685, https://doi.org/10.1108/IJLM-06-20150100 .

Luu, T.T. (2017). CSR and organizational citizenship behavior for the environment in the hotel industry, the moderating roles of corporate entrepreneurship and employee attachment style. International Journal of Contemporary Hospitality Management, 29(11), 2867-2900, https://doi.org/10.1108/IJCHM-02-2016-0080

Scholz, P., \& Voracek, J. (2016). Organizational culture and green management: innovative way ahead in hotel industry. Measuring Business Excellence, 20(1), 41-52, https://doi.org/10.1108/MBE-12-2015-0057.

Sekaran, U., \& Bougie, R. (2016). Research methods for business: A skill-building approach. United Kingdom: John Wiley \& Sons, 235-266.

Siagian, H., Tarigan, Z.J.H., \& Andreani, F. (2019). The influence of information integration on hotel performance through the green operation and strategic purchasing. Proceedings of 2019 the 9th International Workshop on Computer Science and Engineering, 26-31, Hong Kong, 15-17 June. DOI:10.18178/wcse.2019.06.005

Siagian, H., Jade, K., \& Tarigan, Z.J.H. (2020). The role of effective leadership in improving firm performance through the integrated internal system and external integration FMCG industry. International Journal of Data and Network Science, 4(4), 365-372, DOI: 10.5267/j.ijdns.2020.9.002

Slim, A.M., Sarah, O.S., Kadhim, K.G., Ali, B.J., Hammood, A.M., \& Othman, B. (2021). The effect of information technology business alignment factors on performance of SMEs. Management Science Letters, 11(3), 833-842, DOI: $10.5267 / \mathrm{j} . \mathrm{msl} .2020 .10 .019$

Sundram, V.P.K., Bahrin, A.S., Munir, Z.B.A., \& Zolait, A.H. (2018). The effect of supply chain information management and infrastructure information systems: The mediating role of supply chain integration towards manufacturing performance in Malaysia. Journal of Enterprise Information Management, 31(5), 751-770, HTTP: // doi.org/10.1108/JEIM-062017-0084

Tarigan, Z.J.H., Siagian, H., \& Bua, R.R. (2018). The Impact of Information System Implementation to the Integrated System for Increasing the Supply Chain Performance of Manufacturing Companies. IOP Conference Series: Materials Science and Engineering, 473, https://iopscience.iop.org/article/10.1088/1757-899X/473/1/012050.

Tarigan, Z.J.H., Tanuwijaya, N.C., \& Siagian, H. (2020). Does top management attentiveness affect green performance through green purchasing and supplier collaboration? Academy of Strategic Management Journal, 19(4), 1-10, 1939-610419-4-590

Wang, J., \& Dai, J. (2018). Sustainable supply chain management practices and performance. Industrial Management \& Data Systems, 118(1), 2-21, https://doi.org/10.1108/IMDS-12-2016-0540.

Widjaja, B.T., Sumintapura, I.W., \& Yani, A. (2020). Exploring the triangular relationship among information and communication technology, business innovation and organizational performance. Management Science Letters, 10(1), 163-174, DOI: $10.5267 /$ j.msl.2019.8.006

Woo, C., Kim, M. G., Chung Y., \& Rho, J.J. (2016). Suppliers' communication capability and external green integration for green and financial performance in the Korean construction industry. Journal of Cleaner Production, 112, 483-493, https://doi.org/10.1016/j.jclepro.2015.05.119

Xu, L., Prybutok, V., \& Blankson, C. (2019). An environmental awareness purchasing intention model. Industrial Management \& Data Systems, 119(2), 367-381.

Younis, H., Sundarakani, B., \& Vel, P. (2016). The impact of implementing green supply chain management practices on corporate performance. Competitiveness Review, 26(3), 216-245, http://dx.doi.org/10.1108/CR-04-2015-0024

Zhao, L., Huo B., Sun L., \& Zhao, X. (2013). The impact of supply chain risk on supply chain integration and company performance: a global investigation. Supply Chain Management: An International Journal, 18(2), 115-131, https://doi.org/10.1108/13598541311318773 
(C) 2021 by the authors; licensee Growing Science, Canada. This is an open access article distributed under the terms and conditions of the Creative Commons Attribution (CC-BY) license (http://creativecommons.org/licenses/by/4.0/). 